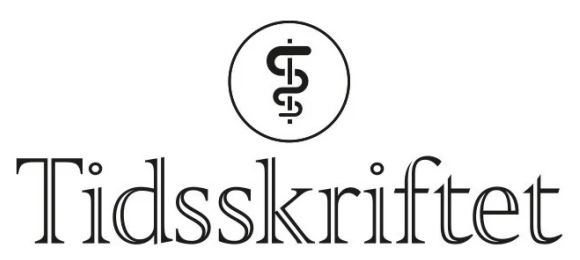

DEN NORSKE LEGEFORENING

\title{
Rusmidler, forgiftninger og legevakt
}

\section{LEDER}

\section{KNUT ERIK HOVDA}

knuterikhovda@gmail.com

Knut Erik Hovda er ph.d. og overlege ved Nasjonal behandlingstjeneste for CBRNE-medisin (CBRNEsenteret), Akuttmedisinsk avdeling, Oslo universitetssykehus og klinisk bakvakt på Giftinformasjonen.

Forfatteren har fylt ut ICMJE-skjemaet og oppgir ingen interessekonflikter.

\section{Inntak av «tradisjonelle» rusmidler som alkohol, cannabis og heroin er fortsatt de viktigste årsakene til rusrelatert forgiftning, viser tall fra Legevakten i Oslo. Nye psykoaktive stoffer kan endre dette bildet.}

Internasjonalt har legevakttjenesten i Norge en unik posisjon, mye takket være LEONprinsippet med behandling på lavest mulig omsorgsnivå (1). Pasienter som ellers hadde fylt opp akuttmottakene, kan således behandles ferdig på legevakt. Slik tjener LEON-prinsippet både pasient, helsetjeneste og samfunnet som den regningsbetalende part. Til tross for en liten populasjon i Norge rapporterer Legevakten i Oslo inn flest forgiftninger av alle sentre til European Drug Emergencies Network(Euro-DEN)(르). Hensiktsmessig prioritering av ressurser kan gi både økonomisk fornuftige pasientsløyfer, men også god trening og kvalitet på tjenestene i front.

Tran og medarbeidere beskriver i studien som nå publiseres i Tidsskriftet, en økning av antall pasienter innen de fleste agensgrupper, med unntak av heroin- og benzodiazepinforgiftninger (3). En typisk forgiftningspasient som legges inn på sykehus, har lav median alder, lav bevissthet og høy risiko for innleggelse i intensivavdeling (4). Likevel, trolig takket være gode behandlingsmuligheter, men også forgiftningenes natur, er sykehusdødeligheten lav (under $1 \%$ ) for denne gruppen (5). Langtidsmortaliteten er derimot skremmende høy (므), med klar sammenheng mellom dødelighet og gjentatte forgiftningsepisoder (7.). Tidligere studier viser at $30 \%$ av pasientene behandles for en ny forgiftningsepisode på et eller annet nivå i helsetjenesten i løpet av ett år, uavhengig av intensjonen bak forgiftningen ( $\underline{8})$. Dette gjør at økningen i antallet rusrelaterte forgiftninger ved legevakten er bekymringsverdig.

Det største antallet henvendelser med rusrelaterte forgiftninger til legevakten er knyttet til de tradisjonelle rusmidlene (3). Imidlertid vet vi at nye psykoaktive stoffer har entret det europeiske markedet i hundretall (9.). Manglende analysekapasitet for disse ved legevakten, samt anerkjennelsen av at man påviste slike stoffer i $8 \%$ av de rusrelaterte 
forgiftningene i Oslo allerede i 2014 (10), gir mistanke om at disse nye rusmidlene med nye omsetningsruter (først og fremst via internett) trolig utgjør en stadig økende andel av de faktiske forgiftningene man registrerer i helsevesenet i dag.

\section{«Til tross for en liten populasjon i Norge rapporterer Legevakten i Oslo inn flest forgiftninger av alle sentre til European Drug Emergencies \\ Network»}

Antallet heroinoverdoser er fallende i Tran og medarbeideres datamateriale, hvilket er gledelig. Samtidige data fra Oslo universitetssykehus som inngår i den samme studien (Euro-DEN), men som foreløpig ikke er publisert, tyder imidlertid på en viss økning i heroinoverdoser i perioden 2014-18. Dette kan skyldes at flere med heroinoverdoser blir mer alvorlig syke, eller at terskelen for sykehusinnleggelse er lavere. Foreløpig har vi i Norge unngått den kraftige økningen av for eksempel illegale fentanylderivater eller forskrevne oksykodonpreparater som man har sett i enkelte land i Europa og USA de seneste årene (3). Den rapporterte økningen i norske politibeslag i 2017-18 er likevel urovekkende (3) og reiser spørsmålet om disse pasientene foreløpig bare har gått under radaren i helsevesenet.

Tran og medarbeidere påpeker at antallet henvendelser med cannabisforgiftninger var $\emptyset$ kende, likeledes at cannabisen var sterkere (3). Gitt et $\emptyset$ kende antall nye syntetiske cannabinoider med andre - til dels mer sentralstimulerende og psykosefremmende egenskaper, savnes likevel en kort kommentar om dette fra forfatterne. Det er kjent at i de fleste tilfellene blir det aldri analysert for disse stoffene, spesielt ikke på legevakt. Oppmerksomheten omkring de nye cannabinoidene bør også følge økt tilfang av slike forgiftninger. Sykehistoriene og pasientenes egne beskrivelser av symptomer ved bruk av disse stoffene vil kunne tilføre nyttig kunnskap til oss som helsepersonell.

Selv om Tran og medarbeidere påpeker at en retrospektiv datainklusjon er en begrensning, gir slike data en bedre kvalitet enn registerstudiene. Forfatterne skal berømmes for både kartlegging av og kunnskapsinnhenting i denne sårbare pasientpopulasjonen. Denne epidemiologiske grunnmuren bør etterfølges av et reisverk av profylakse, terapi og ettervern - der samhandling med tverrfaglig spesialisert rusbehandling danner takkonstruksjonen i et samlet omsorgs- og behandlingsopplegg.

\section{LITTERATUR}

1. Stortingsmelding nr. 9 (1974-1975): Om sykehusbygging m.v. i et regionalisert helsevesen. https://www.stortinget.no/no/Saker-og-publikasjoner/Stortingsforhandlinger/Lesevisning/?p=197475\&paid=3\&wid=b\&psid=DIVL117 Lest 23.3.2021.

2. Dines AM, Wood DM, Yates $C$ et al. Acute recreational drug and new psychoactive substance toxicity in Europe: 12 months data collection from the European Drug Emergencies Network (EuroDEN). Clin Toxicol (Phila) 2015; 53: 893-900. [PubMed][CrossRef]

3. Tran JV, Brekke M, Vallersnes OM. Rusrelaterte forgiftninger ved Legevakten i Oslo i 2014-18. Tidsskr Nor Legeforen 2021; 141. doi: 10.4045/tidsskr.20.0751. [CrossRef]

4. Lund C, Teige B, Drottning P et al. A one-year observational study of all hospitalized and fatal acute poisonings in Oslo: epidemiology, intention and follow-up. BMC Public Health 2012; 12: 858. [PubMed] [CrossRef]

5. Lund C, Drottning P, Stiksrud B et al. A one-year observational multicenter study of treatment and the clinical course in acute poisonings treated in hospitals in Oslo. Scand J Trauma Resusc Emerg Med 2012; 20: 49. [PubMed][CrossRef]

6. Bjornaas MA, Jacobsen D, Haldorsen T et al. Mortality and causes of death after hospital-treated self-poisoning in Oslo: a 20-year follow-up. Clin Toxicol (Phila) 2009; 47: 116-23. [PubMed][CrossRef]

7. Zahl DL, Hawton K. Repetition of deliberate self-harm and subsequent suicide risk: long-term follow-up study of 11,583 patients. Br J Psychiatry 2004; 185: 70-5. [PubMed][CrossRef] 
8. Heyerdahl F, Bjornaas MA, Dahl R et al. Repetition of acute poisoning in Oslo: 1-year prospective study. Br J Psychiatry 2009; 194: 73-9. [PubMed][CrossRef]

9. European drug report 2019: trends and developments. Lisbon: European monitoring centre for drugs and drug addiction (EMCDDA), 2019. https://www.emcdda.europa.eu/publications/edr/trendsdevelopments/2019 Lest 23.3.2021.

10. Vallersnes OM, Persett PS, Øiestad EL et al. Underestimated impact of novel psychoactive substances: laboratory confirmation of recreational drug toxicity in Oslo, Norway. Clin Toxicol (Phila) 2017; 55: 636-44. [PubMed][CrossRef]

Publisert:3. mai 2021. Tidsskr Nor Legeforen. DOI: 10.4045/tidsskr.21.0133

(C) Tidsskrift for Den norske legeforening 2023. Lastet ned fra tidsskriftet.no 26. april 2023. 